\title{
The effectiveness of reducing the daily dose of finasteride in men with benign prostatic hyperplasia Michael J Sullivan* and Jack Geller
}

\author{
Address: 1835 El Cajon Blvd Suite B, San Diego, California, USA \\ E-mail: Michael J Sullivan* - drsullivan@ijm.net; Jack Geller - geller@san.rr.com \\ ${ }^{*}$ Corresponding author
}

Published: 15 January 2002

Received: 16 October 2001

BMC Urology 2002, 2:2

Accepted: 15 January 2002

This article is available from: http://www.biomedcentral.com//47/-2490/2/2

(c) 2002 Sullivan and Geller; licensee BioMed Central Ltd. Verbatim copying and redistribution of this article are permitted in any medium for any noncommercial purpose, provided this notice is preserved along with the article's original URL. For commercial use, contact info@biomedcentral.com

\begin{abstract}
Background: Finasteride, a 5 alpha reductase inhibitor, is an established treatment for benign prostatic hyperplasia. The recommended dosage is $5 \mathrm{mg}$ a day, however case reports have show effectiveness with lower doses. The objective of the current study was to determine in men with benign prostatic hyperplasia, previously treated for at least one year with finasteride $5 \mathrm{mg}$ daily, if they will maintain subjective and objective improvements in urinary obstruction when treated with $2.5 \mathrm{mg}$ of finasteride daily for one year.

Methods: In an open label, prospective study, 40 men with benign prostatic hyperplasia, previously treated for at least one year with $5 \mathrm{mg}$ of finasteride, took $2.5 \mathrm{mg}$ of finasteride daily for one year. Measurements included AUA symptom score, maximum flow rate, voided volume and PSA.

Results: There were no significant changes in maximum flow rate, voided volume, or AUA symptom score after one year of finasteride $2.5 \mathrm{mg}$ daily therapy. PSA increased significantly, $\mathrm{p}<$ $.0 \mathrm{l}$, after one year of finasteride $2.5 \mathrm{mg}$ daily, $2.0+1.4 \mathrm{ng} / \mathrm{ml}$, when compared to finasteride $5 \mathrm{mg}$ daily, I.4+ $1.0 \mathrm{ng} / \mathrm{ml}$.

Conclusions: The daily dose of finasteride can be reduced to $2.5 \mathrm{mg}$ daily without significant effect on subjective and objective measures of urinary obstruction. Although statistically significant increases in PSA are noted when reducing the daily finasteride dose from $5 \mathrm{mg}$ to $2.5 \mathrm{mg}$, the clinical significance of a mean $.6 \mathrm{ng} / \mathrm{ml}$ increase in PSA is questionable.
\end{abstract}

\section{Introduction}

Finasteride is a synthetic inhibitor of human 5 alpha reductase, an enzyme that converts testosterone to dihydrotestosterone (DHT) within the prostate (1). Placebocontrolled studies have demonstrated improvements in subjective and objective measurements of urinary outlet obstruction in men with benign prostatic hyperplasia treated with finasteride $5 \mathrm{mg}$ daily for one year (2). Comparable reductions in DHT levels noted with $5 \mathrm{mg}$ of finasteride have been observed with dosages as low as $1.5 \mathrm{mg}$ $(3,4)$. Given the current monthly cost of $\$ 63$ for $5 \mathrm{mg}$ daily finasteride and the anticipated lifetime requirement for therapy, a less costly maintenance regimen, which is able to control symptoms, would be beneficial.

The current study was undertaken to determine in men with benign prostatic hyperplasia previously treated with finasteride $5 \mathrm{mg}$ daily for at least one year, if $2.5 \mathrm{mg}$ of finasteride daily for an additional year will maintain subjective and objective improvements in urinary obstruction. 
Table I: Mean and standard deviation for maximal flow rate, total voided volume, PSA, AUA score on day I and one year after $2.5 \mathrm{mg}$ of finasteride daily.

Day I I Year

\begin{tabular}{lll} 
Maximal flow rate $\mathrm{cc} / \mathrm{sec} \mathrm{n}=38$ & $13.7 \pm 5.4$ & $13.6 \pm 6.4$ \\
$\begin{array}{l}\text { Voided Volume } 283 \mathrm{cc} \mathrm{n}=38 \\
\text { PSA } \mathrm{ng} / \mathrm{ml} \mathrm{n}=28\end{array}$ & $283 \pm 93$ & $282 \pm 98$ \\
$\begin{array}{l}\text { AUA score } \\
\text { Part A Urinary symptoms } \mathrm{n}=40\end{array}$ & $1.4 \pm 1.0$ & $2.0 \pm 1.4^{*}$ \\
$\begin{array}{l}\text { Part B Problems due to symptoms } \mathrm{n}= \\
\text { 39 }\end{array}$ & $9.6 \pm 5.9$ & $9.3 \pm 5.0$ \\
Part C Quality of life due to urinary & $4.2 \pm 3.2$ & $6.1 \pm 4.3$ \\
\hline
\end{tabular}

problems $\mathrm{n}=39$

${ }^{*} \mathrm{p}<.01$

\section{Patients and Methods}

This was an open label, prospective study involving 40 men with a history of benign prostatic hyperplasia treated for at least one year with $5 \mathrm{mg}$ of finasteride daily. All subjects reported subjective improvement in urinary symptoms with the $5 \mathrm{mg}$ finasteride dose. The study was approved by the institutional review board at Mercy Hospital, San Diego, CA, and all men gave written informed consent.

On day 1 and after one year of therapy with finasteride 2.5 mg a day, subjects completed an American Urological Association Symptom Index form and Quality of Life questionnaire (5), blood was drawn for prostate-specific antigen (PSA), and maximal urinary flow rate and voided volume were determined using a calibrated Dantec urinary flowmeter. The subjects were given a pill cutter and instructed to cut a $5 \mathrm{mg}$ finasteride tablet in half in order to take $2.5 \mathrm{mg}$ daily. Serum PSA was measured using a Hybritech, immunoradiometric assay.

Mean, standard deviation and paired T tests were performed on the day 1 and one year data using Statgraphics Plus statistical software. All tests of significance were twotailed, and all P values of $<.05$ were considered to indicate significance.

\section{Results}

Urodynamic, AUA symptom and quality of life scores, and PSA values on day 1 and one year after $2.5 \mathrm{mg}$ of finasteride daily are presented in Table 1 . There was no significant change in any urodynamic measurement or AUA symptom and quality of life score after one year of finasteride $2.5 \mathrm{mg}$ a day. There was a statistically significant ( $\mathrm{p}$ $<.01$ ) increase in PSA, mean $.6 \mathrm{ng} / \mathrm{ml}$, observed after one year of finasteride at $2.5 \mathrm{mg}$ a day.

\section{Discussion}

The current study has demonstrated, in a select group of men with benign prostatic hyperplasia and symptomatic improvement after treatment with $5 \mathrm{mg}$ a day of finasteride, the dose can be reduced to $2.5 \mathrm{mg}$ daily without significant change in urodynamic measurements of obstruction or worsening of symptoms. The dose of $2.5 \mathrm{mg}$ was selected for the current study because of the relative ease in splitting a $5 \mathrm{mg}$ tablet, but significant improvements in urodynamic measurements and obstructive symptoms have been demonstrated with a $1 \mathrm{mg}$ a day dose (2). The current price of the $1 \mathrm{mg}$ finasteride $(\$ 46.88 / \mathrm{mo})$, approved for alopecia, is more than the cost of splitting a $5 \mathrm{mg}$ tablet in order to obtain the $2.5 \mathrm{mg}$ dose $(\$ 31.50 / \mathrm{mo})$ and the efficacy of reducing the finasteride maintenance dose from $5 \mathrm{mg}$ daily to $1 \mathrm{mg}$ daily has not been investigated.

Gormley, et. al., has reported no significant difference in PSA values at one year for men treated with $1 \mathrm{mg}$ or $5 \mathrm{mg}$ finasteride daily (2). There are no published reports on the effect of finasteride on PSA values for treatment periods greater than one year. The significant increase in PSA, noted after one year of finasteride at $2.5 \mathrm{mg}$ daily in the present study, is of questionable clinical importance given a mean increase of only .6 $\mathrm{ng} / \mathrm{ml}$. However, this may represent a regrowth of prostatic tissue, which may affect urodynamic measurements and symptom scores beyond the one year observation period utilized in this study. When utilizing the PSA for prostate cancer detection in a patient receiving finasteride, it is prudent to recheck the PSA 3-6 months after any finasteride adjustments, in order to determine a new baseline for future reference.

The clinical benefits of $5 \mathrm{mg}$ of finasteride with respect to symptom scores, peak urinary flow rates, and prostatic volumes appears to reach a maximum after 6 months of 
daily therapy (2). Results from the current study would suggest, in those patients with improvement in prostatic symptoms after receiving $5 \mathrm{mg}$ of finasteride daily for 6 months the dose can safely be reduced to $2.5 \mathrm{mg}$ daily.

\section{Competing interests}

None declared.

\section{References}

I. Peters D, Sorkin E: Finasteride. Drug 1993, 46:177-208

2. Gormley $G$, Stoner $E$, et al: The effect of finasteride in men with benign prostatic hyperplasia. NEJM 1992, 327:1185-91

3. McConnell J, Wilson J, et al: Finasteride, an inhibitor of $\mathbf{5}$ alpha reductase, suppresses prostatic dihydrotesteosterone in men with benign prostatic hyperplasia. JCEM 1992, 74:505-8

4. Vermeulen A, Giagulli P, et al: Hormonal effects of an orally active 4-azasteroid inhibitor of 5 alpha reductase in humans. The Prostate 1989, 14:45-53

5. Barry M, Fowler $F$, et al: The american urological association symptom index for benign prostatic hyperplasia. J Urol 1992, I 48: 1549-57
Publish with BioMed Central and every scientist can read your work free of charge

"BioMedcentral will be the most significant development for disseminating the results of biomedical research in our lifetime."

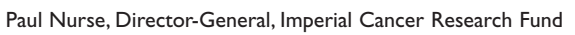

Publish with BMC and your research papers will be:

- available free of charge to the entire biomedical community

- peer reviewed and published immediately upon acceptance

- cited in PubMed and archived on PubMed Central

- yours - you keep the copyright

Submit your manuscript here:

http://www.biomedcentral.com/manuscript/
BioMedcentral.com editorial@biomedcentral.com 